\title{
Detection of Russian olive witches'-broom disease and its insect vector in Northwestern Iran
}

\author{
Abasalt Hajizadeh, Reza Khakvar*, Nemat Sokhandan Bashir, Leila Zirak \\ Department of Plant Protection, Faculty of Agriculture, University of Tabriz, 5166616471, Tabriz, Iran
}

Vol. 57, No. 3: 309-313, 2017

DOI: 10.1515/jppr-2017-0028

Received: January 3, 2017

Accepted: July 12, 2017

*Corresponding address:

khakvar@tabrizu.ac.ir

\begin{abstract}
Recently, Russian olive trees showing witches'-broom and little leaf symptoms have been widely observed in northwestern and central Iran. Polymerase chain reaction (PCR) and nested PCR assays using phytoplasma universal primer pairs confirmed phytoplasma symptomatic infection of trees. Sequence analyses showed that 'Candidatus Phytoplasma asteris' was the causal agent of the disease in these regions. However, RFLP results using restriction enzymes HpaII, EcoRI, HinfI and AluI indicated that the collected isolates in these regions are genetically different. In addition, leafhopper Macropsis infuscata was recognized as a possible insect vector of the disease for the first time.
\end{abstract}

Key words: 'Candidatus Phytoplasma asteris', Macropsis infuscate, phytoplasma, Russian olive

\section{Introduction}

Russian olive (Elaeagnus angustifolia) is a tree native to Iran and is widely grown in several climatic zones. Several pathogens infect Russian olive trees worldwide, one of which is phytoplasma. So far, only one phytoplasma species has been identified which infects Russian olive. Russian olive witches'-broom disease, caused by 'Candidatus Phytoplasma asteris' ('Ca. Phytoplasma asteris'), was reported for the first time in central and northwestern regions (Urmia and Tehran) of Iran (Rashidi et al. 2010). In this study, we found that the ' $\mathrm{Ca}$. Phytoplasma asteris' isolates which infect Russian olive trees in northwestern Iran are genetically different from each other. Furthermore, a leafhopper species was recognized which is thought to be a natural vector of Russian olive witches'-broom disease in these regions.

\section{Materials and Methods}

Fifteen Russian olive trees showing phytoplasma-associated symptoms including witches'-broom, rosetting, little leaf, dieback in Ilkhchi, Shabestar, Khameneh, Azarshahr, Miyaneh and six locations in green, urban areas of Tabriz, all located in East Azerbaijan province in northwestern Iran, were sampled. During the sample collection (June to October of 2012 and 2013), some insects including a leafhopper species were collected on symptomatic trees to investigate their association with vectoring the pathogen.

Total nucleic acid was extracted from the leaf midrib tissues of each sample and from insect bodies according to Zhang et al. (1998). Extracted DNAs were subjected to polymerase chain reaction (PCR) and nested PCR assays using the primer pairs P1/Tint (Smart et al. 1996) and R16F2n/R16R2 (Lee et al. 1993), respectively, for detection of the phytoplasma. In addition, scions were prepared from symptomatic trees and grafted onto healthy Russian olive seedlings as well as periwinkle shrubs. The DNA samples, extracted from midribs of newly grown leaves of the grafted seedlings, were also subjected to the PCR assays.

Then, restriction fragment length polymorphism (RFLP) analyses using HpaII, EcoRI, HinfI and AluI restriction enzymes were carried out to determine 
the diversity among the phytoplasma isolates collected from different areas. In the RFLP analyses, Iranian cherry phytoplasma PCh8 (accession number: FJ204397), which was previously collected from central Iran (Zirak et al. 2009), and one almond phytoplasma isolate related to 16SrIX phytoplasma group (isolate P25) which was collected in an area near the investigated regions were used as the reference strains for ' $\mathrm{Ca}$. Phytoplasma asteris' and pigeon pea witches'-broom group respectively.
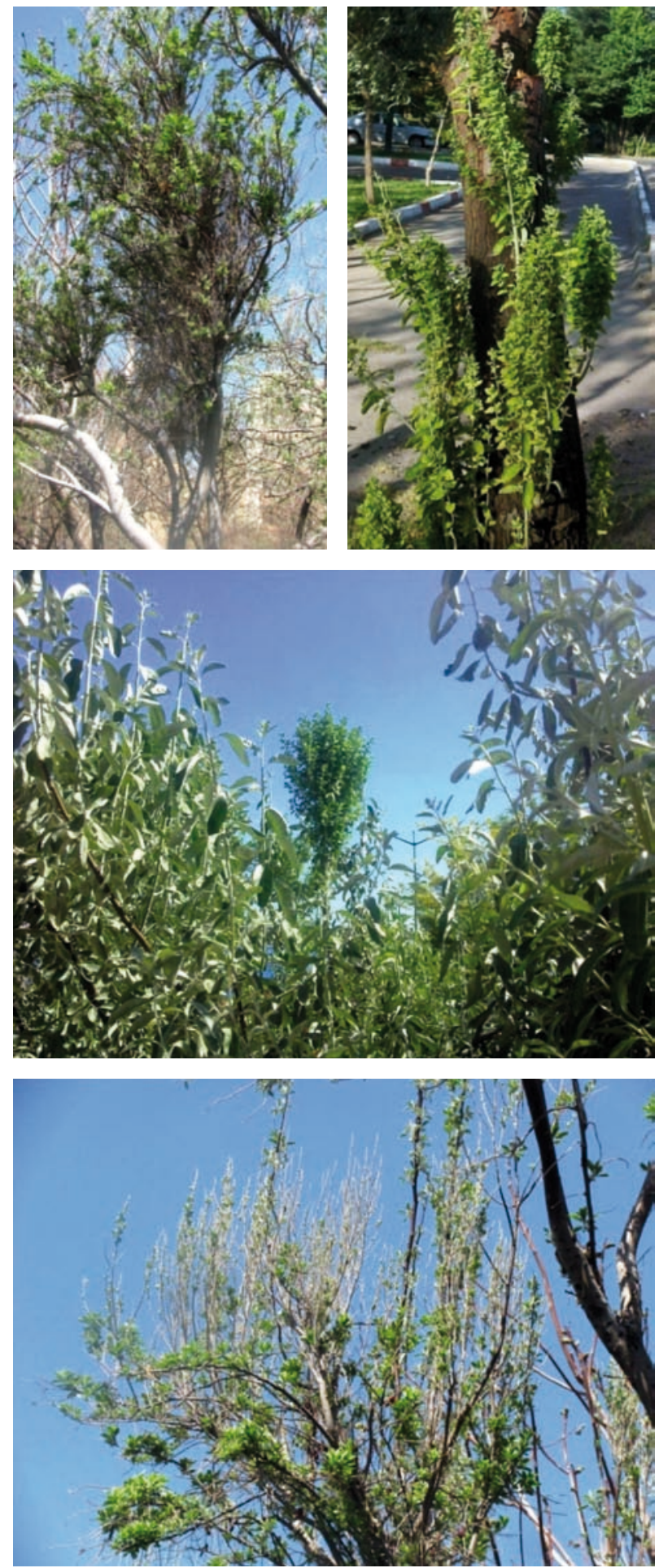

Fig. 1. Symptoms of Russian olive witches'-broom disease in East Azerbaijan province, Iran
Finally, a 1,239 bp fragment amplified in the nested PCR was sequenced and submitted to GenBank as accession number: KJ920334 ('Elaeagnus angustifolia' witches'-broom phytoplasma). A phylogenetic tree was constructed using partial 16S rRNA sequences of Russian olive witches'-broom phytoplasma and some phytoplasmas in GenBank using Mega5 software.

\section{Results and Discussions}

Russian olive witches'-broom disease symptoms are similar in the all surveyed areas (Fig. 1). To determine how the disease spreads, cuttings of symptomatic Russian olive trees were grafted onto healthy Russian olive seedlings and periwinkle plants. After one month, the grafted periwinkles and seedlings showed little leaf and rosetting symptoms (data not shown). Polymerase chain reaction and nested PCR assays which were done using DNA samples extracted from healthy, symptomatic trees and graftings resulted in the presence of a 1,239 bp fragment confirming infection with phytoplasmas in all collected symptomatic Russian olive trees and grafted scions. In addition, one leafhopper species which was the most numerous of all the insects collected from the canopy of symptomatic Russian olive trees was recognized as Macropsis infuscata (Sahlberg) (Hemiptera: Cicadellidae) (Fig. 2). Nested PCR
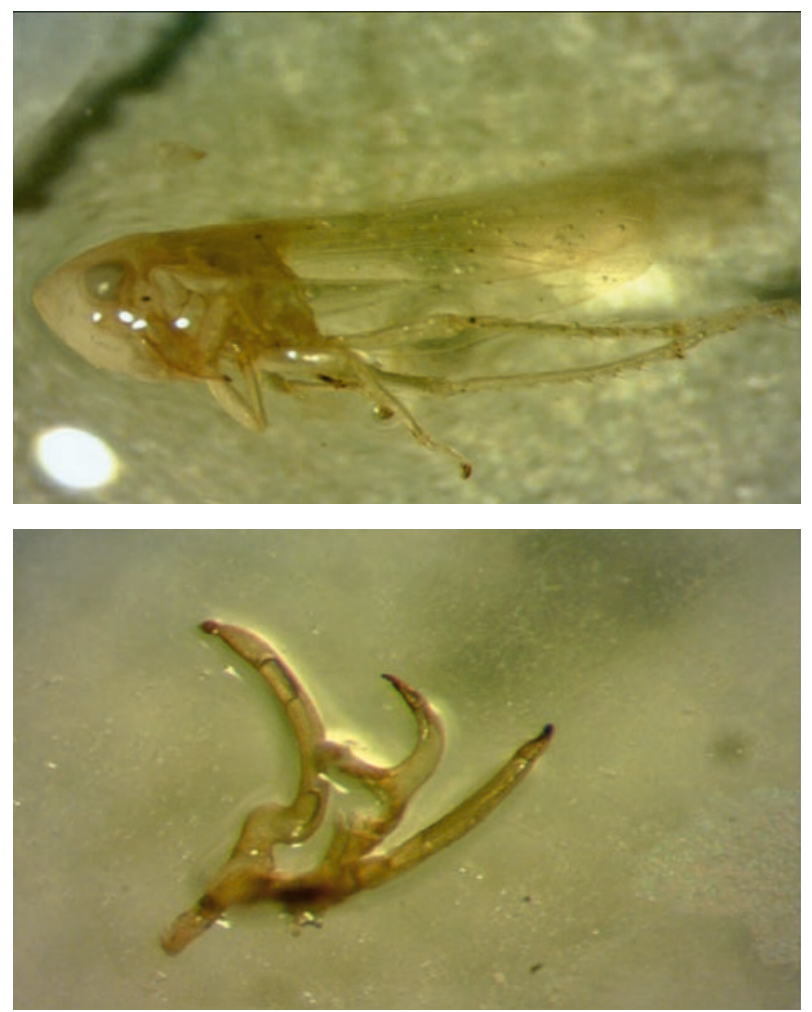

Fig. 2. The leafhopper Macropsis infuscata (upstairs) and its genitalia (downstairs) - natural vector of Russian olive witches'broom disease in East Azerbaijan province 

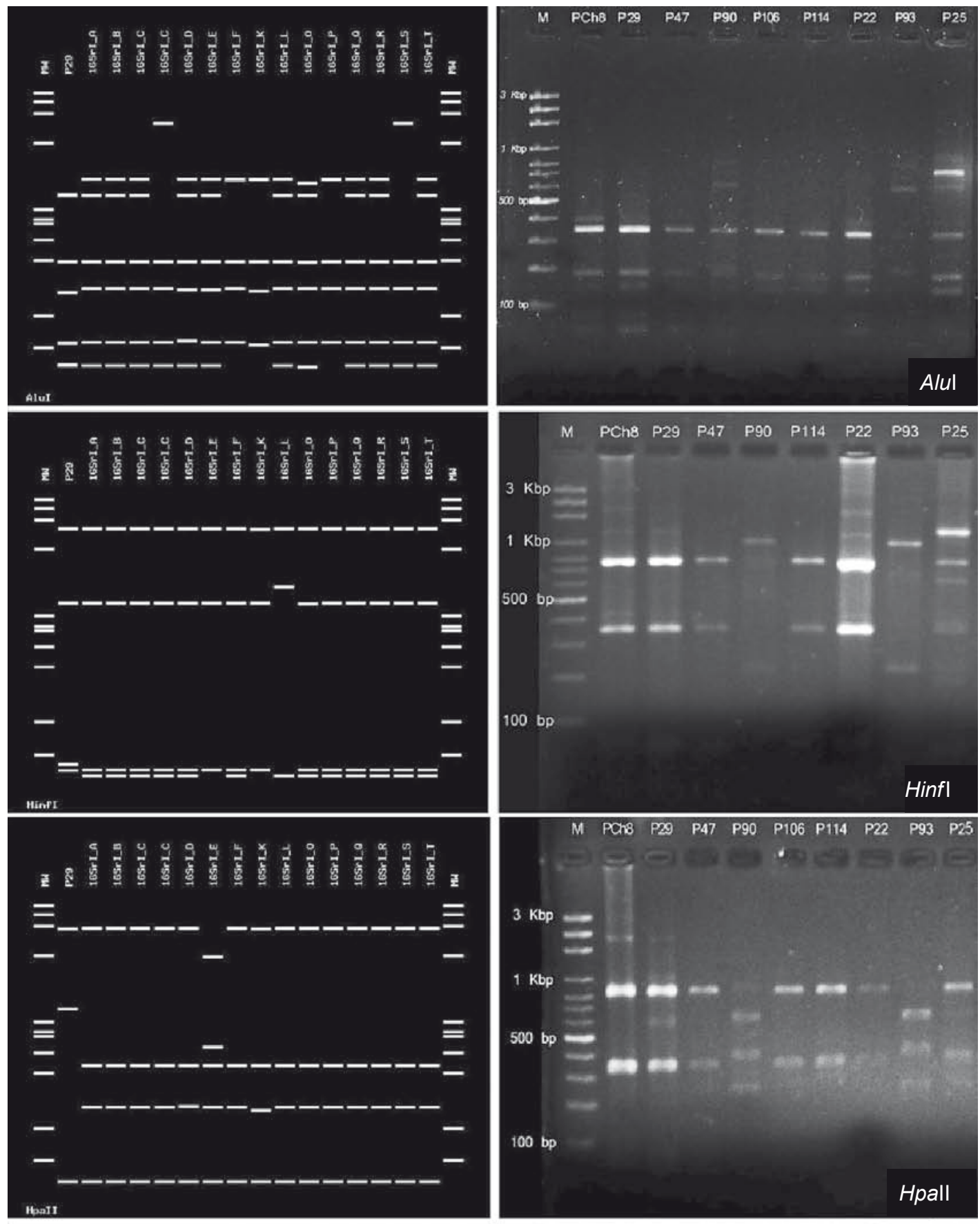

Harit
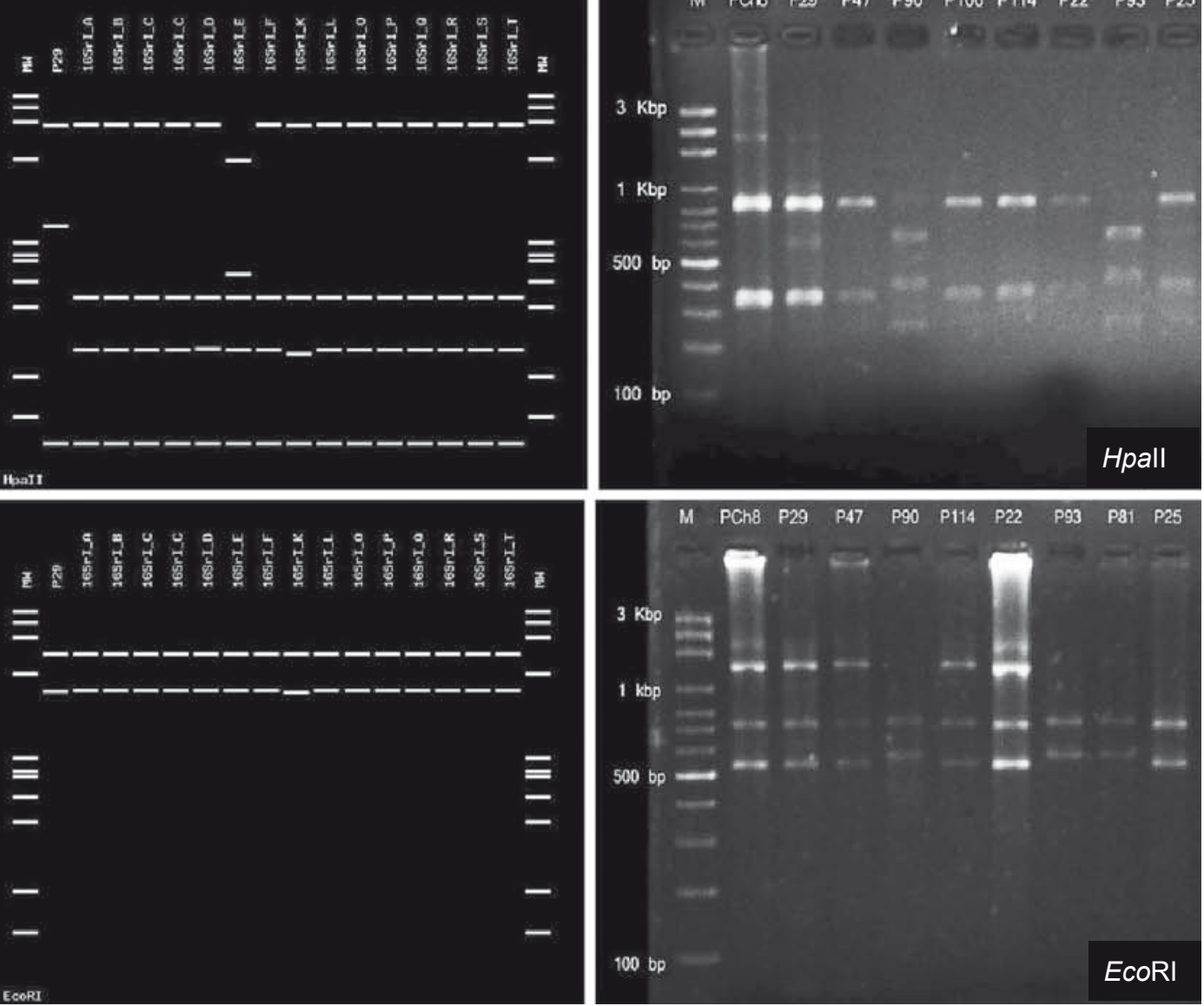

EcoRI
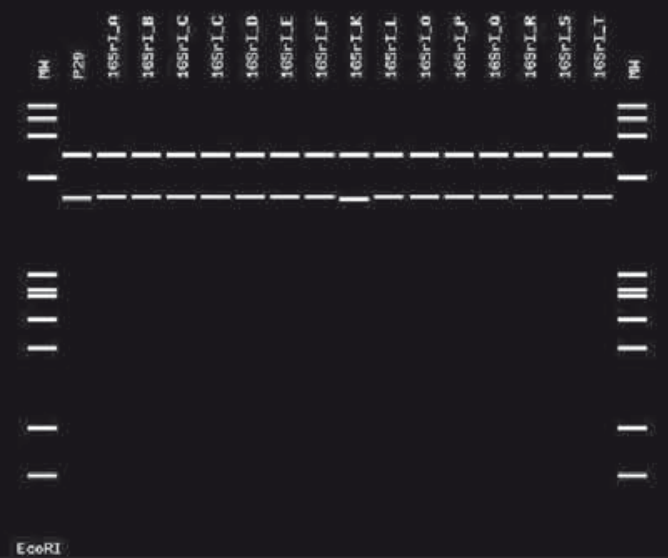

Fig. 3. Virtual (on the left) and real (on the right) RFLP analyses of 1,239 bp fragment from Russian olive witches'-broom phytoplasma isolates using restriction enzymes Hpall, EcoRl, Hinfl and Alul. Isolate PCh8 is Iranian cherry phytoplasma PCh8 (FJ204397), related to 'Candidatus Phytoplasma asteris' and isolate P25 is a almond phytoplasma isolate belonging to $16 \mathrm{SrIX}$ group 
positive results showed that these leafhoppers were affected by the phytoplasma. Therefore, $M$. infuscata is possibly a natural insect vector of the disease in East Azerbaijan province.

Restriction fragment length polymorphism results indicated that all collected Russian olive phytoplasma isolates shared patterns similar to that of isolate PCh8 using restriction enzymes HpaII, EcoRI, Hinfl and AluI whereas isolates P90 and P93 which were collected from one area in green, urban areas of Tabriz shared different patterns and therefore probably belong to different subgroups. Virtual RFLP analyses results using these four enzymes showed patterns very similar to actual RFLP patterns (Fig. 3).

Blast analysis of a representative sequence (isolate P29) indicated that Russian olive phytoplasma from East Azerbaijan province ('E. angustifolia' witches'-broom phytoplasma) shared $99.1 \%$ similarity with 'Ca. Phytoplasma asteris' reference strain (accession number: M30790), 99.68\% identity with Iranian pear phytoplasma PD33 (accession number: KC902810) from Isfahan in the center of Iran (Hashemi et al. 2014b), and $98.79 \%$ identity with Russian olive witches'-broom phytoplasma (accession number: EU886968) which was previously reported from West Azerbaijan, a neighboring province of East Azerbaijan (Rashidi et al. 2010).

The phylogenetic tree which was constructed using parsimony analysis of partial $16 \mathrm{~S}$ rRNA sequences confirmed that ' $E$. angustifolia' witches'-broom phytoplasma in Iran is related to ' $\mathrm{C} a$. Phytoplasma asteris' (Fig. 4).

'Ca. Phytoplasma asteris' is the causal agent of the disease on several annual and herbaceous plants (Vali-Sichani et al. 2014a, b). However, few perennials have been reported that can be affected by ' $\mathrm{Ca}$. Phytoplasma asteris' in Iran (Zirak et al. 2009; Hashemi-Tameh et al. $2014 \mathrm{a}, \mathrm{b})$. It was expected that ' $\mathrm{Ca}$. Phytoplasma asteris' was the causal agent of Russian olive witches'-broom disease in the investigated regions. Symptoms of the disease were identical in all regions and were similar to previously reported symptoms (Rashidi

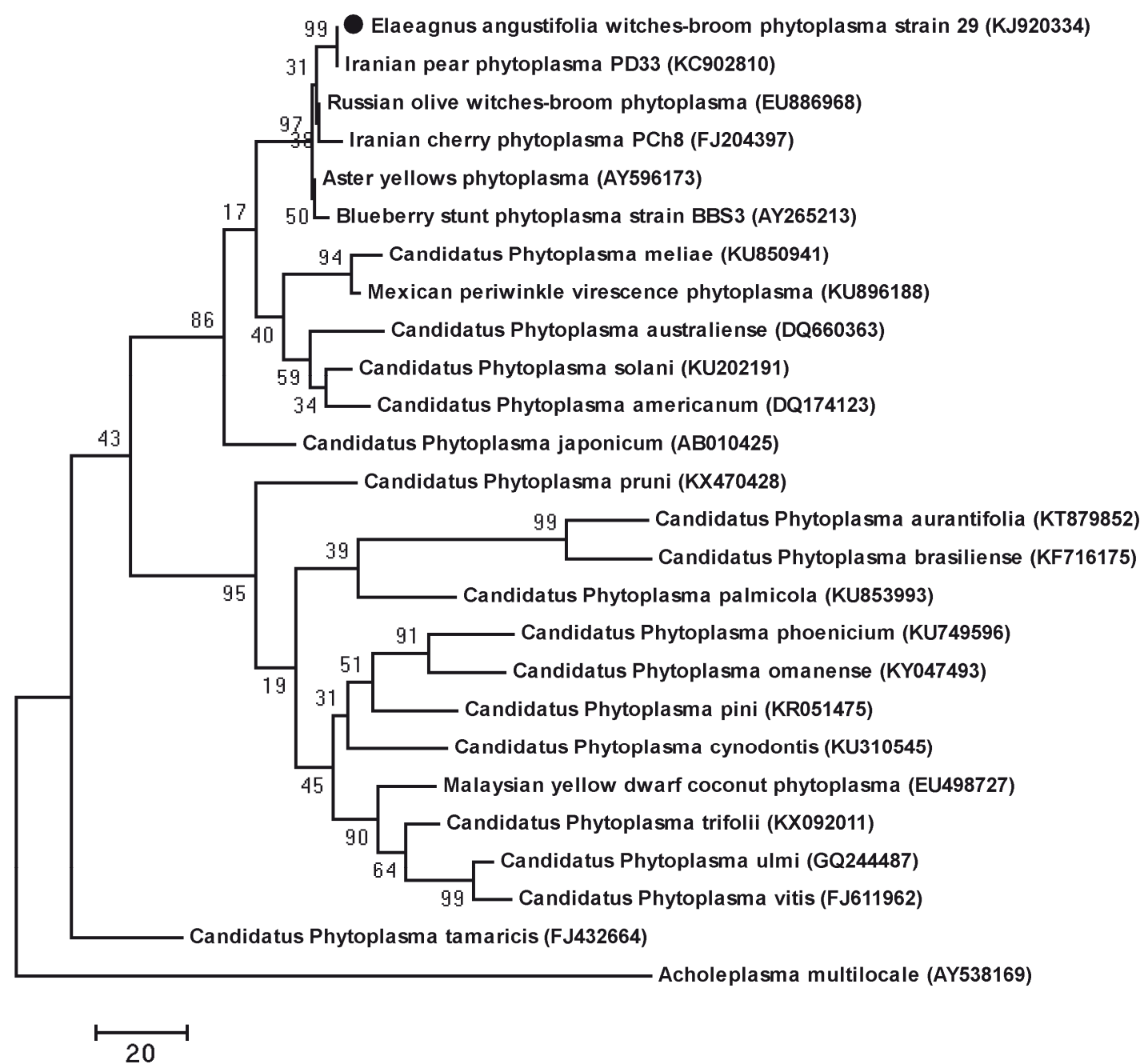

Fig. 4. Phylogenetic tree constructed using parsimony analysis of partial $16 \mathrm{~S}$ rRNA sequences from 24 phytoplasmas, one 'Elaeagnus angustifolia' witches'-broom phytoplasma and an Acholeplasma multilocale isolate as outgroup of the tree. Bootstrapping was done in 1,000 replications. - reference strain in this research 
et al. 2010). However, the results from this study revealed that the isolates collected from different areas were genetically different from each other. Diseased trees showing similar symptoms were observed in different areas in northwestern, central, and probably other parts of Iran. Therefore, the disease is probably transmitted by infected seedlings and the leafhopper $M$. infuscata in several areas. This is the first report of Russian olive witches'-broom disease in East Azerbaijan province and the first identification of its possible insect vector worldwide.

\section{Acknowledgements}

The authors would like to thank the staff of the bacteriology, mycology and virology labs in the Department of Agriculture, University of Tabriz for their support in performing this project.

\section{References}

Hashemi-Tameh M., Bahar M., Zirak L. 2014a. ,Candidatus Phytoplasma asteris' and 'Candidatus Phytoplasma aurantifolia', new phytoplasma species infecting apple trees in Iran. Journal of Phytopathology 162 (7-8): 472-480. DOI: https://doi.org/10.1111/jph.12216

Hashemi-Tameh M., Bahar M., Zirak L. 2014b. Molecular characterization of phytoplasmas related to apple proliferation and aster yellows groups associated with pear decline dis- ease in Iran. Journal of Phytopathology 162 (10): 660-669. DOI: https://doi.org/10.1111/jph.12245

Lee I.M., Hammond R.W., Davis R.E., Gundersen D.E. 1993. Universal amplification and analysis of pathogen 16 S rDNA for classification and identification of mycoplasma like organisms. Phytopathology 83 (8): 834-842. DOI: https://doi. org/10.1094/phyto-83-834

Rashidi M., Chosta Y., Bahar M. 2010. Molecular identification of a phytoplasma associated with Russian olive witches' broom in Iran. European Journal of Plant Pathology 127 (2): 157-159. DOI: https://doi.org/10.1007/s10658-010$-9589-\mathrm{X}$

Smart C.D., Schneider B., Blomquist C.L., Guerra L.J., Harrison N.A., Ahrens U., Lorenz K.H., Seemuller E., Kirkpatrick B.C. 1996. Phytoplasma-specific PCR primers based on sequences of the 16S-23S rRNA spacer region. Applied and Environmental Microbiology 62 (8): 2988-2993.

Vali Sichani F., Bahar M., Zirak L. 2014a. Characterization of phytoplasmas related to 'Candidatus Phytoplasma asteris' subgroup rpI-L in Iran. Journal of Plant Protection Research 54 (2): 199-203. DOI: https://doi.org/10.2478/jppr$-2014-0030$

Vali Sichani F., Bahar M., Zirak L. 2014b. Characterization of phytoplasmas related to aster yellows group infecting annual plants in Iran, based on the studies of $16 \mathrm{~S}$ rRNA and $r p$ genes. Journal of Plant Protection Research 54 (1): 1-8. DOI: https://doi.org/10.2478/jppr-2014-0001

Zhang Y., Uyemoto J.K., Kirkpatrick B.C. 1998. A small-scale procedure for extracting nucleic acids from woody plants infected with various phytopathogens for PCR assay. Journal of Virological Methods 71 (1): 45-50. DOI: https://doi. org/10.1016/s0166-0934(97)00190-0

Zirak L., Bahar M., Ahoonmanesh A. 2009. Characterization of phytoplasmas related to 'Candidatus phytoplasma asteris' and peanut WB group associated with sweet cherry diseases in Iran. Journal of Phytopathology 158 (1): 63-65. DOI: https://doi.org/10.1111/j.1439-0434.2009.01566.x 